CZU:398.3(478)+39(478)(092)

https://doi.org/10.52505/filomod.2021.15.34

\title{
DOCUMENTAREA OBICEIURILOR CALENDARISTICE DE IARNĂ ÎN STUDIILE LUI PETRE V. ȘTEFĂNUCĂ
}

\author{
VICTOR PLETOSU \\ Institutul de Filologie Română „Bogdan Petriceicu-Hasdeu”
}

Rezumat. In perioada interbelică, etnologul Petre V. Ștefănucă observă că datina colindatului a supraviețuit veacurilor și este un fenomen viu în practica folclorică. În lucrările sale de importanță enciclopedică „Cercetări folclorice pe Valea Nistrului de Jos” și „Datinile de Crăciun și Anul Nou pe Valea Nistrului de Jos", etnologul Petre V. Ștefănucă ne atrage atenția asupra conservării și documentării datinilor de Crăciun și Anul Nou pe Valea Nistrului de Jos, precum şi a repertoriului de colinde, cântece de stea și plugușoare circumscrise sărbătorilor de iarnă, a teatrului folcloric desfășurat în cadrul său natural ca element identitar românesc, deoarece tradițiile etnofolclorice revitalizează spiritul național și exprimă specificul etnic.

Cuvinte-cheie: tradiții etnofolclorice, zone etnografice, conservarea și promovarea patrimoniului cultural imaterial, cercetări de teren, teatru popular.

Abstract. In the interwar period, the ethnologist Petre V. Ștefãnucă observes that the tradition of caroling has survived for centuries and is a living phenomenon in folk practice. In his works of encyclopedic importance, „Folklore research on the Lower Dniester Valley” and „Christmas and New Year customs on the Lower Dniester Valley", he draws our attention to the conservation and documentation of Christmas and New Year customs, as well as the repertoire of carols, star songs and plows circumscribed for the winter holidays, the folklore theater developed in its natural setting as an element of Romanian identity, because ethno folkloric traditions revitalize the national spirit and express ethnic specificity.

Keywords: ethno folkloric traditions, ethnographic areas, preservation and promotion of intangible cultural heritage, field research, popular theater.

Patrimoniul etnofolcloric reprezentativ al sărbătorilor de iarnă cuprinde frumoase și vechi tradiții sub forma unor paradigme lăsate de strămoșii noștri pentru a păstra și respecta, cu sfințenie, ordinea și viața satului, normele eticii și esteticii populare, disciplinei și ordinii sociale. Alaiul cetelor de colindători faimoși face legătura între case asemeni unui brâu protector al satului, interpretând un repertoriu valoros de creații folclorice muzicale, literare, coregrafice și teatrale. Totodată reflectă, în mod artistic, gândirea și poziția înțeleaptă a poporului față de esențele primordiale ale vieții: armonia om - natură - divinitate, muncile câmpului, traiul și trecerea ireversibilă 
a timpului. Analiza comparativistă a obiceiurilor și tradițiilor calendaristice sporește interesul tinerei generații pentru cunoașterea specificului imanent al patrimoniului cultural național în contextul celui european.

Sub auspiciile Institutului de Cercetări Sociale al României, Regionala Chișinău, conform principiilor științifice ale Școlii sociologice de la București, fondată de academicianul Dimitrie Gusti, etnologul Petre V. Ștefănucă a contribuit esential la cercetarea și sistematizarea materialelor etnofolclorice privind obiceiurile calendaristice de iarnă, înregistrate în satele (vetre ale colindelor în ceată bărbătească) din cuprinsul entității etnografice „Valea Nistrului de Jos" pentru a ne cunoaște rădăcinile, simbolurile arhaice și reperele noastre identitare (Botezatu, 2006; Ștefănucă, 1991; Ștefănucă, 2006; Trofimov, 2004). Etnograful subliniază că a ales acest spațiu etnocultural, deoarece, în această regiune, spre deosebire de satele din celelalte părți ale Basarabiei, datinile s-au păstrat cu mult mai bine și mai întregi.

În studiul Datinile de Crăciun și Anul Nou pe Valea Nistrului de Jos, publicat în anul 1938 în Buletinul Institutului de Cercetări Sociale al României, Regionala Chișinău, Petre V. Ștefănucă face o remarcă: „de la un timp, datinile de Crăciun și Anul Nou au început să fie foarte mult căutate de către instituțiile noastre culturale" (Ștefănucă, 2008, p. 331). Folcloristul ne mărturisește că la orașe datinile au devenit obiect de demonstrație teatrală, pe când la sate, îndeosebi în Basarabia, datinile sunt pe cale să dispară. Insă, dispariția datinilor este un semn de sărăcie, de secătuire a bogățiilor spirituale ale unui popor. Totodată, harnicul cercetător ne sugerează: „Datinile nu trebuie să rămână numai subiecte de admirație, la zile mari, ci se cade să formeze esența vieții spirituale românești în zile de sărbători. Opera de reînviere a datinilor strămoșești trebuie înfăptuită, în primul rând, la sate" (Ștefănucă, 2008, p. 332).

În scopul promovării și perpetuării tradițiilor de Crăciun și Anul Nou sub forma unor splendide spectacole pe arena culturală a poporului, la 27 decembrie 1937, Institutul Social Român din Basarabia, în colaborare cu Fundația Culturală Regală „Principele Carol”, Regionala Basarabiei, și cu Conservatorul Municipal din Chișinău, au organizat, în Chișinău, o serbare a datinilor de Crăciun și Anul Nou, unde au participat cetele de colindători din satele Corcmaz și Palanca din județul Cetatea Albă, îndrumate de cucernicii preoți din aceste localități. Sensul profund al acestei opere de protejare și de revitalizare a datinilor strămoșești este înregistrarea obiceiurilor și colindelor care exprimă conștiința națională, iar colindătorii și intelectualii spectatori și-au recăpătat încrederea în datinile noastre, și au convingerea că sunt moștenitorii acestor comori intelectuale, și nu se vor lăsa ușor ispitiți ca să-și înstrăineze datinile. Astfel, Petre V. Ștefănucă documenta colindele și obiceiurile, alături de colegul său, Vasile Popovici, profesor la Conservatorul Municipal din Chișinău, care nota textele muzicale.

Etnologul Petre V. Ștefănucă descrie structura etnică a satelor de pe Valea Nistrului de Jos, locuite de români, ucraineni și rușii care au fugit de 
armată de pe moșiile boierești din Rusia, descoperind treceri de elemente din cultura unui popor la alt popor, obiceiurile fiind amestecate în cadrul manifestărilor spirituale de Crăciun și Anul Nou: „Românii, având aceeași religie ortodoxă ca și ucrainenii, se căsătoresc între ei fără nici un obstacol. Căsătoriile între români și rușii sectanți (staroobreadți) se fac rar, deoarece aceștia din urmă pretind ca românii să treacă la secta lor. În aceste sate sunt multe familii mixte, unde limba română și rusă se vorbește în mod curent" (Ștefănucă, 2008, p. 333).

Petre V. Ștefănucă notează că în satele de pe Valea Nistrului de Jos, se păstrează următoarele datini de Crăciun: Tăiatul porcilor, Schimbul lichiilor, Steaua, Luceafărul și Colindatul. Detalii interesante surprindem din descrierea etnografică a sărbătorii Sf. Ignat. Pe 20 decembrie, la Ignat, se taie porcii pentru masa de sărbătoare. Îl pârlesc, îl spală și-l învelesc cu țoale și cu paie ca să se suie copiii călare. Îl taie, îi scot măruntaiele, scot beșica și o umplu cu porumb ca să se joace copiii cu dânsa.

Un alt obicei cunoscut în satele de pe Valea Nistrului de Jos e „Schimbul lichiilor" în Ajun de Crăciun - un simbol al legăturilor de rudenie, care se întâlnește numai la români. Prin „lichii” se înțelege o turtă din făină de grâu nedospită, făcută din resturile ce se rad de pe covată, când coc pâine gospodinele. Copiii de până la 12 ani pun pe aceste turte bomboane și fructe și le pun într-o basma şi se duc în grupuri pe la casele naşilor și ale rudelor. Copiii intră în casă, sărută mâna gospodarilor și strigă „V'o trimes tata și mama lichie!". Gospodina casei ia lichiul și pune altul la loc, copt de ea. Prin acest obicei sătenii ,se țin de neamuri”.

Obiceiul „Cu Steaua” este cunoscut la Palanca, dar are de suferit din cauza schimbării calendarului. În trecut colindau copiii „Cu Steaua” în ziua de Crăciun cântând: „Steaua sus răsari / Ca o tainî mari, / Steaua lumineazî / Șî adevereazî. / Steaua strălucești / Șî lumii vestești”" (Ștefănucă, 2008, p. 346). Cete de câte 12 flăcăi stelari colindă „Cu Steaua” și „Cu Luceafărul”, pe care le joacă în ritmul melodiei, interpretând la fereastră cântecul de stea Trei crai di la răsărit. Admirăm frumusețea acestor cântări cu text evanghelic ce oglindește etosul creștin al neamului nostru. Când intră în ogradă, colindătorii întreabă de la poartă dacă primește „Cu Steaua” în casă. Cetele de stelari din Palanca pleacă și în satele vecine să colinde. Stelarii poartă costume speciale, făcute din șuvițe de hârtie colorată, încleiate pe benzi de pânză. Steaua are nouă cornuri și în vârful cornurilor e încinsă cu un brâu de hârtie colorată. În centru e fixată icoana Nașterii Domnului Iisus Hristos în iesle. La capătul fiecărui corn e un canaf de hârtie colorată. Steaua și Luceafărul simbolizează că s-a născut împăratul întregului univers, iată de ce sunt păstrate la loc de cinste, în timpul anului, la un flăcău din fruntea cetei, iar dacă acesta se însoară, sunt transmise altui tânăr.

Colindatul este cel mai spectaculos obicei, cu caracter public, în cadrul căruia este antrenată toată comunitatea. Este un spectacol în care își dau 
concursul aproape toți locuitorii satului, care inițiază tineretul în obiceiurile comunității și stimulează competiția artistică între cetele de colindători, fiecare străduindu-se să dețină poziția dominantă. Petre V. Ștefănucă constată că obiceiul colindatului este cel mai bine păstrat. „Rezistența acestei datini se datorește, poate, și împrejurărilor că românii conlocuiesc, în unele sate, cu ucrainenii și rușii, la care știm că această datină este foarte însemnată. Textele de colinde rusești și românești, culese de la aceiași informatori, sunt o mărturie despre trecerea acestei datini de la un popor la altul" (Ștefănucă, 2008, p. 335). Deși, colindele românești au suferit puternice influențe din partea colindelor ucrainene, se colindă curent în două limbi: română și ucraineană, în următoarele sate: Chițcani, Copanca, Leontina, Corcmaz, Tudora și Palanca. Astfel, din consemnările folcloristului, observăm că, totuși, se mai aud încă multe colinde românești interpretate de copii, flăcăi și bărbați însurați, care colindă toate cele trei zile de Crăciun. Colindele românești sunt vechi și cuprind numeroase motive pe care le întâlnim în colindele din Ardeal și din Moldova, având subiecte mult mai poetice decât cele religioase. Motivele caracteristice colindelor românești ce răsună pe Valea Nistrului de Jos sunt: șoimul, murgul, Ștefan-Vodă și un bour ce poartă între coarne un legăn de mătase, în care șade fata gazdei și coase. În studiul Cercetări folclorice pe Valea Nistrului de Jos, publicat în anul 1937, în Anuarul Arhivei de Folclor din București, Petre V. Ștefănucă ne explică aceste reminiscențe istorice: „Se aude și legenda descălecatului Moldovei, cu interesante substituiri de locuri și personaje. Cel care vânează «buhaiu», nu este Dragoș, ci Ștefan cel Mare, iar vânătoarea se petrece pe apele Nistrului de Jos până la Odesa. Aici se îneacă Molda, și nu pe valea Siretului” (Ștefănucă, 2008, p. 151).

Copiii și flăcăii învață colindele rusești fără să le înțeleagă sensul și, astfel, textul colindelor apare cu totul ciuntit. Ziua, până la asfințitul soarelui, colindă la fereastra casei, copiii de până la 12 ani, care au învăţat colindele încă din postul Crăciunului de la bătrâni. Sunt înzestraţi cu puritate morală și candoare, și aduc, cu sinceritate, vestea bucuriei în sufletul gospodarilor, interpretându-le colinda copilărească: ,Sculați, sculați, boieri mari, / Lerulea Doamne, / Vă sculaț și Vă spalţ, / La icoani Vă 'nchinați/ Ș’aprindiț făcliili, / Șî dischidiț porțâli” (Ștefănucă, 2008, p. 331). După asfințitul soarelui colindă băieții de la 12 la 16 ani, iar mai târziu, până după miezul nopții, umblă numai flăcăii, mai ales pe la casele unde sunt „,cumpănii” (petreceri). La Palanca, bărbații însurați colindă pe la rude. În concepția populară, gospodăria colindată are bucurie și roadă bogată tot anul împrejur.

Remarcabilul etnolog descrie structura actanțială a colindatului. Protagoniștii se grupează în cete de până la 12 flăcăi, care se adună și învață colindele la casa unuia dintre ei sau la „hurdughie”. Aici are loc alegerea membrilor cetei după criteriul talentului și al calităților artistice cu care este înzestrat fiecare, cu condiția că este cuminte și nu s-a compromis cu fapte urâte. Totodată, se întâmplă și repartizarea funcțiilor. În fruntea cetei este ales 
starostele după criteriul prestigiului și al experienței. Acesta era supranumit „,bireoza”, pentru că începea colindele, el primește colacul, strânge banii și tot el „ceterează” colacul. Conducătorul cetei are autoritate și responsabilitate, precum și multe atribuții ce țin de relația de comunicare a cetei cu comunitatea. Tot el era supranumit și cămărașul, ajutat de un „,sâtori” sau doi „hăznători”: unul strânge colacii, altul adună banii. Cămărașii aleg un „cămărașu mari” care stă la „hurdughie” și dimineața ,prinește socotiala di la cămăraș”. La „hurdughie» sau la Hora satului se desfãşoară actul iniţiatic, când novicii de 18 ani „,ies în lumea flăcăilor” și se socializează cu ceilalți flăcăi în cadrul șezătorilor, și se împacă, de cu toamnă, să fie acceptați în ceată și să dea o vadră de vin. Când dă vadra, conducătorul cetei strigă: „Gura ficioarii, flăcăi!”. Ceilalți flăcăi chiuie și-1 dau „ura” (îl ridică pe brațe în sus) de 3 ori. După acest ritual de trecere la majorat, flăcăul își alege o fată „după plăcerea și starea lui" și ,șade (vorbește) cu dânsa”. La întrunirile speciale ale flăcăilor de la „hurdughie” avea loc pregătirea și învățarea repertoriului de colinde, orații și dansuri, în funcție de vatra etnografică, dar și de specificul curților gospodarilor care urmează a fi colindați. De asemenea, era confecționată vestimentația și atributica rituală.

Astfel, din cercetările folcloristice ale profesorului Petre V. Ștefănucă, desprindem tiparele scenariului tradițional cutumiar distinct, o structură organizatorică a obiceiului „Colindatul”, ce cuprinde trei etape generale de practicare: etapa pregătitoare și de constituire a cetelor, apoi colindatul din casă în casă, cu interpretarea creațiilor și răsplata gospodarilor, precum și etapa de încheiere, spre dimineață, la „hurdughie”, cu totalul încasărilor pentru a dărui o parte din sumă bisericii, dar și pentru a arvoni lăutarii ce vor cânta la Hora satului.

Exegetul conturează și o structură cronotopică. $\mathrm{Cu}$ vreo două-trei zile înainte de Crăciun, se adună flăcăii din sat la „hurdughie” și aleg dintre ei trei flăcăi care se duc la preot după binecuvântare, precum și la primarul localității ca să ceară învoire pentru a umbla cu colindatul prin sat și „sî’mpaci din preț pintru colindat”. Preotul le dă „crușca” pentru adunat banii. Cetele își împart satul în sectoare de colindat, în funcție de cât de mare este localitatea, „ca să nu îmble douî ceti pe-un loc”, deoarece, o ceată nu are voie să colinde pe sectorul altei cete. Ceata de flăcăi colindă, mai întâi la preot, apoi la primarul localității, apoi prin sat, de dimineață până seara, în toate cele 3 zile de Crăciun. Colacii pe care îi câștigă îi împart între ei, dar banii îi duc la biserică. După cele trei zile de Crăciun, se duc din nou la preot și la primar ca „să cumperi plugăriili”.

După ce au umblat pe la toate casele, cetele de colindători se întrunesc la „hurdughie”. Prin ,hurdughie” se înțelege o casă veche sau casa pe care o „,nănesc” (închiriază) flăcăii de la un gospodar din sat, pe tot timpul sărbătorilor de iarnă. Aici aduc toate darurile pe care le câștigă cu „,colindatul” sau cu „,hăitul”. Tot în curtea acestei case flăcăii organizează ,jiocul”, în cele 3 zile 
de Crăciun, de Anul Nou și de Bobotează. Hora din aceste zile de sărbătoare se numește „hurdughie”. Când se spune că „mă duc la hurdughie” se înțelege că „mă duc la hora (jiocul) din curtea „hurdughiei” - locul unde se-ntâlnesc flăcăi cu fete. A treia zi de Crăciun, seara, vin la „hurdughie” toți flăcăii din sat și se împart în cete pentru a merge cu plugușorul în ajunul Anului Nou. După ce s-au organizat cetele și au împărțit satul în sectoare de colindat, flăcăii rămân la „hurdughie” până dimineața. Aici beau, cântă și dansează toată noaptea. Chiria „hurdughiei” o plătesc din banii adunați cu colindatul sau cu hăitul. O parte din acești bani sunt destinați pentru a cumpăra steaguri, vase și odăjdii pentru biserică sau veșminte preoțești, sau pentru a fi construită fântâna flăcăilor, sau pentru plata lăutarilor angajați pentru a cânta la hora satului, sau pentru a înălța un monument în cinstea eroilor neamului.

În Ajunul Anului Nou copiii umblă cu Plugușorul după-amiază și zic: „Hăi, daț colacu șî pitacu, / Vă fărâmî boii pragu! Hăi!” (Ștefănucă, 2008, p. 155). Ei poartă un plugușor de lemn cu busuioc și lână roșie. Seara, flăcăii umblă cu „Plugu sial mari”. Ei poartă un plug mic împodobit cu busuioc (ce poartă noroc și e simbolul dragostei), legat cu lână roșie (firul vieții), un clopot care vestește bucuria anului nou și alungă anul vechi, precum și un buhai. Se colindă cu Plugușorul numai la români și ucraineni. „Cămărașu mari” și flăcăii lui aleg 6 case de gospodari cu fete frumoase, bune de măritat și le spunea celorlalți flăcăi să nu se ducă pe la aceste case. Fetele alese sunt anunțate din timp ca să se pregătească cu masă. Ele invită rudele și vecinii. Este o deosebită onoare pentru gospodăria unde a fost ,aleasă fata”. Cămărașul mare cu lăutarii se duce la fiecare fată aleasă, intră în casă, dă „Bună seara!”, dă mâna cu părinții și cu fata, recită Pluguşorul, doar flăcăii strigă „Hăi!’. După ce urează, sunt poftiți la masă. Gospodarii demonstrează cinstea și respectul pentru ceata de colindători. Fata mare le dă un colac mare, împodobit frumos cu busuioc și 50 de lei. Apoi cămărașul invită fata la horă. E lesne de înțeles, că funcția premaritală și propițiatorie a tradiției de a scoate fata la horă este motivația tineretului de a valorifica și păstra tradițiile etnofolclorice circumscrise sfintelor sărbători de iarnă.

Petre V. Ștefănucă este înzestrat cu dexteritatea de a face din actul artistic un act de cunoaștere. Ne impresionează talentul său literar de a reda coloristica obiceiurilor de iarnă cu jocul celor mai de seamă măști atractive, haioase, comice și împodobite, ce conturează un spectacol miraculos și plăsmuiesc feeria și farmecul iernii. Despre Malanca ne povestește că se umbla în ajun de Anul Nou în satele rusești: Chițcani și Leuntea. Malanca o fac flăcăii. Se adună câte 5-6 flăcăi și se îmbracă în haine femeiești. Un flăcău are un harapnic cu care trosnește și dă de știre stăpânului că vine Malanca. Cântă întâi afară la fereastră „A uciora iz vecera / Pasla Milanca dva caciora / Pasla i pasla zagubila / U cistâi poli zabludila / Ore i ore / Vsio pohoniaet / Vsio na Milancu pohliadae” (în traducere: „Ieri seară / Păștea Milanca două rațe, / Le-a păscut și păscându-le le-a pierdut. / S-a rătăcit în câmpul verde, / Plânge și plânge, 
căutându-le într-una. / Toți o admiră pe Milanca") (Ștefănucă, 2008, p. 331). Apoi intră Malanca în casă. La început bocește și apoi prinde a dansa cu un flăcău numit Vasile, care intră cu dânsa. Alt flăcău le cântă de joc din harmonică ori vioară. După ce joacă dau mâna cu toți cei din casă, iar stăpânul, în semn de mulțumire, le dăruie colaci, cârnați, ouă, bani și câte un pahar de vin. „În trecut se obișnuia să se umble cu «Malanca» la Copanca și la Cormaz, atât la români, cât și la ucraineni. Ucrainenii din aceste două sate, fiind complet românizați, astăzi acest obiceiu a dispărut" (Ștefănucă, 2008, p. 156).

Efectul magnific al cetei de colindători este mai pronuntat gratie virtuozității jocului „Căluțul” - o reprezentație de teatru popular, performată de Anul Nou. Umblă o ceată de 9-12 flăcăi și fete (băieți îmbrăcați în haine femeiești). La acest obicei se face următoarea distribuție a rolurilor: un flăcău e căpitanul care poartă centură, o sabie-n brâu și căluțul de frâu, și îi spune când să joace. Al doilea flăcău joacă căluțul, care este construit astfel, încât, plăsmuiește imaginea unui călăreț călare pe cal. Căluțul nu are picioare. El saltă cu picioarele jucătorului. Urmează apoi un doctor îmbrăcat în halat alb ce poartă o trusă de instrumente și medicamente cu el. Negustorul jidan Iancu poartă o lădiță de mărunțișuri. Cât trec de la o casă la alta, două-patru fete se prind în joc, la auzul muzicii, cu doi-patru moșnegi îmbrăcați în cojoace și căciuli întoarse pe dos. Un viorist e nemascat și cântă sârba și cazaciocul, tot timpul cât umblă cu căluțul. Un flăcău cu clopotul umblă pe la case și întreabă dacă primesc să joace Căluţul în casă sau afară. Când intră în casă, căpitanul începe urătura Căluțului: „Aho Aho, căluțul tati / De trei ani și jumătate!”. Căluțul saltă și se face că sare în două picioare și se smulge din frâu. Flăcăul cu clopotul ,,ceterează” Plugușorul: „Sara lui Sfântu Vasâle / Întru mulț ani să Vă fii / Gospodarilor cu bini. / Cî sara o'nsărat, / Șî noi pe Duneavoastră nu V'am urat!” (Ștefănucă, 2008, p. 372). Când strigă flăcăii „Hăi!”, căluțul saltă. După ce se termină Plugușorul, vioristul cântă o sârbă, moșnegii și fetele se prind la joc. Deodată, căluțul cade. Atunci vioristul începe o melodie duioasă, o doină. Doctorul se repede la gura căluțului și-i dă pe la gură cu medicamente. Ceilalți se apleacă înspăimântați să vadă ce s-a întâmplat cu căluțul, care sare deodată în picioare. Atunci vioristul cântă o melodie săltăreață. Toți joacă în jurul căluțului. Negustorul vinde pe la fete și neveste mărgele, oglinjoare, săpunuri, imitând, în vorbire, pe negustorii evrei. Doctorul se repede, în glumă, la femei și bărbați ca să le scoată măselele.

Folcloristul Petre V. Ștefănucă atestă practici magico-ritualice pentru căsătorie. În ajunul Anului Nou, fetele care vor să se mărite fac o mulțime de vrăji ca să-și cunoască ursitul. Leagă parii de la gard cu busuioc. Dacă parul este cioturos, este semn că are noroc. Tot în această zi li se arăta fetelor dacă se vor mărita în curând sau vor trebui să mai aștepte. Se duceau la Nistru și aduceau apă cu gura. Luau o mână de făină și frământau și făceau turte mici „bubușleli”, pe care le însemnau și le dau la câine. Pe care turtă câinele o ia prima, acea fată se va mărita mai degrabă. 
Sunt interesante prevestirile vremii în concepția populară. În satele cercetate era cunoscut calendarul cu coji de ceapă. Gospodina făcea trei metanii, tăia cepele, le punea pe fereastră, presura sare în ele și însemna cele 12 luni ale anului. Dimineața vedea cum va fi fiecare lună a anului - în care ceapă sarea se topește și lasă must apoi acea lună va fi ploioasă. Se credea, că dacă la Crăciun, Anul Nou și Bobotează ninge din abundență, atunci anul va fi mănos cu roadă bogată și grâu din belșug.

În ziua de Anul Nou copiii umblă cu „Semănatul”. Când seamănă cu grăunțe de porumb, strigă cu bucurie: „Sănătatea Noului / Și la anul cu sănătate!". În semn de recunoștință gospodarii le dăruiesc colaci și sămânță de bani. Bărbații și femeile, când vin în ospeție de Sfântul Vasile, intră în casă și zic: „Să Vă fii di bini cu Anul Nou!”. Mai rar se-ntâmplă, numai în Copanca, ca flăcăii să umble cu semănatul. Cămărașii se duc la fetele alese. Când intră în casă spun cu mândrie: „Să Vă fie de bine cu Sfântul Vasile, / Să crească grâiele, mălaiele și popușoaiele!’. Cămărașii aleg o pereche de colaci frumoși și-i închină la o fată aleasă. Mama fetei cumpără colacii, dându-le câte 20-30 de lei.

A două zi după Anul Nou e sărbătorită moașa. Se duc femeile la moașă cu colaci, cu bani și cu daruri. Baba se gătește cu mâncare. Se așază la masă, cinstesc și spun glume pentru a înveseli moașa. Apoi o primblă pe moașă cu sania.

„Cu Capra” astăzi nu se mai umblă în nici un sat. În trecut, însă se pare că a existat și acest obicei. Se înscena și „Irozii”. Un alt obicei dispărut e „Chiraleisa”. După cum își amintesc localnicii, „Cu Chiraleisa” colindau copiii de până la 10 ani, în ajunul Bobotezei, pe la neamuri, pe la nănași, pe la vecini. Aveau în mână o cruce de lemn, făcută de meșteri, împodobită cu prosop și busuioc, și strigau: „Chiraleisa, Doamni, / Câti chetriseli în fântână, / Atâtia oali cu smântânî!”. La Copanca, „Cu Chiraleisa” colindau doi-trei flăcăi, cu o cruce de lemn și ziceau: „Chiraleisa, Doamni, / Cai înhămători, / Boi înjugători, / Stogurili groasî, / Fetili frumoasî, / Chiraleisa, Doamni!" (Ștefănucă, 2008, p. 156). La Bobotează, creștinii merg la biserică, iau agheasmă și stropesc via și grădinile de pomi fructiferi ca Dumnezeu să le ferească de boli.

Din cele relatate de Petre V. Ştefănucă, deducem că, organizarea colindătorilor pe cete și întrunirea lor sub o singură conducere, la ,hurdughie”, are o mare însemnătate pentru viața comunității. Prin această datină, se cultivă tineretului pasiunea pentru tezaurul estetic popular, sentimentul de coeziune socială, ideile de solidaritate națională, precum și de sacrificiu pentru binele obștesc. Datinile de Crăciun și Anul Nou sunt mult mai bine păstrate și devin admirabile mijloace de educare a tineretului de la sate pentru a asigura comunicarea și solidaritatea între generații, pentru a consolida memoria socială și culturală a colectivității și pentru a menține apărarea comunităţii tradiționale. Colindatul este actul ritual-ceremonial, la care participă toată 
comunitatea: colindătorii și colindații. Este un pilon esențial de afirmare a identității naționale istorico-culturale. Actualmente, argumente, în acest sens, ne aduce academicianul Sabina Ispas, care a demonstrat că tradiția colindatului relevă unitatea, specificitatea și identitatea națională. De asemenea, fenomenul etno-cultural al colindatului a fost studiat mai profund de Nicolae Băieșu în cele două volume ale monografiei Obiceiurile și folclorul sărbătorilor de iarnă, contribuție substanțială a eminentului profesor la cercetarea și sistematizarea materialelor etnofolclorice privind obiceiurile calendaristice de iarnă, înregistrate pe teren de laboriosul cercetător preocupat de salvgardarea moștenirii culturale a românilor.

Avem datoria morală să continuăm programul profesorului Petre V. Ștefănucă de a ilustra modalitățile de expresie ale tradițiilor noastre etnofolclorice, vechi, pitorești și înțelepte, cu valențe estetice, artistice și cognitive, ce oglindesc prospețimea eposului popular și înnobilează imaginea bogăţiei poporului nostru, vigoarea și rodnicia pământului. Folcloristul ne sugerează că tradiția colindatului nu este o simplă repetiție, ci un fenomen viu, care evoluează și exercită o complexitate de funcții importante: funcția de protecție (apotropaică), de purificare, de vindecare, de fertilitate sporită. Funcția spectaculară, de divertisment artistic și de petrecere este deosebit de relevantă. De asemenea, funcția cognitivă (de întoarcere la izvoare, la rădăcini); funcția de felicitare; funcția estetică - de transmitere a valorilor; funcția psihologică - care exprimă stările de bucurie ale personajelor; funcția de a vesti Nașterea Domnului Hristos, deoarece colindul nu face distincție: bogat - sărac, căci toți acei cărora se adresează colindătorii sunt boieri, gospodari, stăpâni, jupâni.

Cercetările monografice Datinile de Crăciun și Anul Nou pe Valea Nistrului de Jos și Cercetări folclorice pe Valea Nistrului de Jos cuprind și o diversitate tipologică a colindelor în funcție de fondul ideatic, sentimental, dar și tematic: cântece de stea, colinde interpretate de copii, colinde tradiționale, colinde care omagiază gospodarii cu turme de oi și lanuri de grâne, colinde cosmogonice și religioase care evocă motive despre facerea lumii, colinde cu funcție premaritală pentru fată mare. Totodată, scot în evidență structurile sociale: hurdughia, ceata de colindători consacrați, care cuprinde floarea flăcăilor de frunte, cumpăniile între neamuri și hora satului, care reprezintă constituentele ce caracterizează originalitatea comunităţii tradiţionale românești, vizează relațiile sociale și educarea generațiilor de copii și tineri în spiritul creatorilor și purtătorilor de patrimoniu cultural imaterial viu.

În concluzie, Valea Nistrului de Jos rămâne a fi o arie a colindatului în ceată bărbătească, unde românii, conlocuind, în multe sate, cu ucrainenii, s-au influențat reciproc. Întâlnim colinde și obiceiuri românești adoptate de ucraineni, precum și colinde și obiceiuri ucrainene adoptate de români. Aplicarea textului în limba română sau ucraineană la aceeași melodie de colindă este destul de frecventă. Fenomenul cel mai interesant ce se întâlnește 
la români e practicarea unei polifonii populare pe două și chiar pe trei voci, executată după o manieră specific ucraineană. $\mathrm{Cu}$ toate influențele ce se resimt în colinde din partea ucrainenilor, repertoriul de colinde românești este incomparabil mai bogat și mai variat ca motive literare și muzicale, decât repertoriul de colinde ucrainene.

La finele lucrărilor citate mai sus, ilustrul savant etnolog și folclorist își exprimă speranța că vor reînvia, în satele de pe Valea Nistrului de Jos, cele mai frumoase datini românești din partea de răsărit a țării. Aceste datini cuprind un spectru de elemente ancestrale semnificative pentru identitatea națională și reprezintă un material didactic pentru educarea generațiilor în creștere în spiritul dragostei de neam și țară. O acțiune de revitalizare a datinilor întreprind, în ultimul timp, căminele culturale, care an de an, se pătrund, tot mai mult, de însemnătatea datinilor în viața spirituală a unui popor și organizează de sărbători cete de colindători care promovează repertoriul de colinde românești identificate în localitățile de baștină sau în cele din vecinătate.

\section{Referințe bibliografice:}

1. BOTEZATU, Grigore. Petre Ștefănucă - profesor-etnolog, martir al renașterii naționale (Mărturii documentare). În: Revistă de lingvistică și știință literară. 2006, nr. 5-6, p. 66-83.

2. ȘTEFĂNUCÂ, Petre V. Folclor și tradiții populare. Alcătuire, studiu introductiv, bibliografie, comentarii și note de Grigore Botezatu și Andrei Hîncu. Vol. I - II. Chișinău: Știința, 1991.

3. Ștefănucă Petre (1906-1942). Autorul proiectului, texte stabilite, note de Grigore Botezatu. Chișinău: Eleña, 2006.

4. ȘTEFĂNUCĂ, Petre V. Datini și creații populare. Text ales și stabilit, studiu introductiv, note și comentarii de Grigore Botezatu. Chișinău: Știința, 2008.

5. TROFIMOV, Maria. Folcloristul și etnograful Petre V. Ștefănucă. În: Revistă de lingvistică și știință literară. 2004, nr. 1-3, p. 36-43.

Notă: Articolul a fost realizat în cadrul proiectului de cercetare 20.80009.1606.03 Contexte socioculturale autohtone şi interconexiuni europene în creaţia populară şi literatura cultă din Basarabia (sec. XIX până în prezent), Institutul de Filologie Română „B. P.-Hasdeu” al MEC. 